\title{
HYDROCHEMICAL PROPERTIES OF SPRINGS SLATINSKI IZVOR AND SOLENICA (REPUBLIC OF MACEDONIA)
}

\author{
HIDROKEMIJSKE LASTNOSTI IZVIROV SLATINSKI IZVOR \\ IN SOLENICA (REPUBLIKA MAKEDONIJA)
}

\author{
Biljana GIČEVSKI ${ }^{1}$, Slavčo HRISTOVSKI ${ }^{2}$, Vojo MIRČOVSKI ${ }^{3} \&$ Blažo BOEV $^{3}$
}

\begin{abstract}
UDC 556.114:556.36(497.7)

Biljana Gičevski, Slavčo Hristovski, Vojo Mirčovski \& Blažo Boev: Hydrochemical properties of springs Slatinski Izvor and Solenica (Republic of Macedonia)

Hydrochemical properties of water samples from the Slatinski Izvor spring and Solenica spring were analyzed during the period between December 2011 - November 2013. The wider area around the springs belongs to two tectonic units. The first is the Pelagonian horst-anticlinorium and is composed of carbonate rocks. The second is the Western Macedonian zone, and it is composed of non-carbonate rocks. The Slatinski Izvor spring is located on the Pelagonian horst anticlinorium, and the Solenica spring is situated on a fault which separates the two tectonic units. The measurements of the temperature, conductivity and the hydrochemical analysis indicate that both springs have different hydrochemical properties. The major cations in the Slatinski Izvor spring were $\mathrm{Ca}^{2+}$ and $\mathrm{Mg}^{2+}$, and anions were $\mathrm{HCO}_{3}^{-}$and $\mathrm{SO}_{4}^{2-}$, the water had temporary hardness and it belongs to calcium hydrogencarbonate water type. The Slatinski Izvor spring had typical shallow and fresh water. The major cations in the Solenica spring were $\mathrm{Na}^{+}$and $\mathrm{Ca}^{2+}$, and anions were $\mathrm{Cl}^{-}$and $\mathrm{HCO}_{3}^{-}$. The water belongs to $\mathrm{NaCl}$ water type which is typical of deep ancient ground water.

Key words: hydrochemistry, karst spring Slatinski Izvor, salt spring Solenica.
\end{abstract}

\begin{abstract}
Izvleček
UDK 556.114:556.36(497.7)

Biljana Gičevski, Slavčo Hristovski, Vojo Mirčovski \& Blažo Boev: Hidrokemijske lastnosti izvirov Slatinski izvor in Solenica (Republika Makedonija)

Hidrokemijske lastnosti vodnih vzorcev iz izvirov Slatinski izvor in Solenica so bili analizirani v obdobju od decembra 2011 do novembra 2013. Širše območje izvirov pripada dvema tektonskima enotama. Prvi je Pelagonijski horst-antiklinorij in je sestavljen iz karbonatnih kamnin. Druga je Zahodnomakedonska cona in je sestavljena iz nekarbonatnih kamnin. Slatinski izvor se nahaja v Pelagonijskem horst-antiklinoriju, Solenica pa na prelomu, ki ločuje obe tektonski enoti. Merjene temperature in električne prevodnosti ter hidrokemijske analize kažejo na razlike v hidrokemijskih lastnostih obeh izvirov. Glavna kationa v izviru Slatinski izvor sta bila $\mathrm{Ca}^{2+}$ in $\mathrm{Mg}^{2+}$, aniona pa $\mathrm{HCO}_{3}^{-}$in $\mathrm{SO}_{4}^{2-}$, voda je imela karbonatno trdoto in pripada kalcij hidrogenkarbonatnemu tipu. Slatinski izvor je imel tipično plitvo in sladko vodo. Glavna kationa v izviru Solenica sta bila $\mathrm{Na}^{+}$in $\mathrm{Ca}^{2+}$, aniona pa $\mathrm{Cl}^{-}$in $\mathrm{HCO}_{3}^{-}$. Voda pripada $\mathrm{NaCl}$ tipu, ki je značilen za globoko, staro podzemno vodo. Ključne besede: hidrokemija, kraški izvir Slatinski Izvor, slani izvir Solenica.
\end{abstract}

\footnotetext{
${ }^{1}$ Exploring Society “Ursus speleos”, Dobromir Hrs 20 a, 1000 Skopje, Republic of Macedonia, e-mail: biljana_speleo@yahoo.com ${ }^{2}$ Institute of Biology, Faculty of Natural Sciences and Mathematics, Ss. Cyril and Methodius University. Arhimedova 3, 1000 Skopje, Republic of Macedonia, e-mail: slavco_h@pmf.ukim.mk

${ }^{3}$ Institute of Geology, Faculty of Natural and Technical Sciences, University “Goce Delčev”, Goce Delčev 89, 2000 Štip, Republic of Macedonia
}

Received/Prejeto: 01.03.2015 


\section{INTRODUCTION}

Karst rocks may be one of the most important aquifer formations because most of the time they contain abundant groundwater resources (Bakalowicz 2005), and some of the most significant freshwater quantities are stored in karst aquifers. Efficient management and protection of groundwater resources relies on knowledge of groundwater systems (Trček \& Zojer 2010). However, because of their specific nature and unique hydrogeological characteristics, karst aquifers require specifically-adapted investigation methods. Hydrochemical methods are some of the suitable methods which primarily serve to assess water quality and study contamination problems in karst (Hunkeler \& Mudry 2007) but also help to locate and quantify the mineralization of the water, provide information about the structure of the aquifer, and help for better understanding of water-rock interactions.

Usually, karst springs are the main sampling points. Spring chemistry reflects the nature of the recharge area that feeds the spring (Palmer 2007) and provides information about the functioning of the karst system.

The total area of the karst in Macedonia covers $3078 \mathrm{~km}^{2}$ or $12 \%$ of the country surface. The largest karst region is the Poreče basin with $427.5 \mathrm{~km}^{2}$ or $13.9 \%$ of the total karst area (Temovski 2012). The karst springs are important water resources in Macedonia for the settlements in the western part of the country, including the capital of Skopje. The karst springs in the Poreče region (Slatinski Izvor, Pešna, Manastirec) represent significant potential for water supply, especially due to the absence of pollution sources. However, the water quality of these springs has not been a subject of a recent study. Furthermore, Slatinski Izvor area is important from the hydrogeological and speleological point of view and thus it is protected as Macedonian Monument of Nature and it is on the tentative list of UNESCO World Heritage Sites.

In our study the main goal was to determine the hydrochemical properties of the springs Slatinski Izvor and Solenica (Poreče, Republic of Macedonia) and to assess their possible origin. The hydrochemistry of the spring Solenica has been described previously by Jenko (1956), Kotevski (1987) and Gičevski \& Hristovski (2013). In this study, hydrochemical properties of water samples from the Slatinski Izvor spring and Solenica spring were analyzed during the period between December 2011 and November 2013.

\section{STUDY AREA}

The springs Solenica and Slatinski Izvor are located in the Poreče basin of West - Central Macedonia. The spring Solenica is located in the village Slatina (foothills of Pesjak Mountain) and the spring Slatinski Izvor is $2.5 \mathrm{~km}$ distant from the same village, in the southeast direction. Both springs are situated in the river valley of Slatinska Reka and they are part of the protected area Monument of Nature "Slatinski Izvor".

The east part of the study area (Fig. 1) is composed of pre-Cambrian dolomite marbles which are tectonically crushed and well karstified. In the west part Paleozoic quartz-sericite schists and metasandstones, metarhyolite tuffs, muscovite-chlorite-quartz schists and epidotechlorite-amphibole schists prevail, which are moderately-permeable rocks with fissure porosity. The rocks from the Mesozoic age are represented by aplitic granite with fissure porosity, located between the marbles and the Palaeozoic rocks. The carbonate rocks are covered with Pliocene sediments (gravel, sands, and clay) which are highly-permeable rocks with intergranular porosity. Quaternary sediments are represented by moraines on the upper parts of Pesjak Mountain, and alluvium which fills the river bed of the river Slatinska Reka - both of these units have intergranular porosity.

The area is dissected with a fault between the Pelagonian and Western Macedonian tectonic units oriented in the NW-SE direction, and traced for more than $50 \mathrm{~km}$ (Dumurdzanov et al. 2005) with a width of 10-100 m (Dumurdzanov et al. 1979). There is a reverse fault between the villages of Slatina and Zrkle in the NW-SE direction, and a covered fault on the river bed of Krušeska Reka in the NW-SE direction.

The river Slatinska Reka, which is the left (western) tributary of the river Treska, sinks at the contact between the carbonate and non-carbonate rocks, therefore the river bed is dry during the summer. In the part of the river valley which belongs to the protected area, there are three springs. The largest and the most important spring is Slatinski Izvor which serves as a cave entrance for the Slatinski Izvor cave (Fig. 2). It is an intermittent spring that flowed for nine months during the first year of study. It is also captured for water supply. Its discharge varies between 0 and $100 \mathrm{~L} \cdot \mathrm{s}^{-1}$. The spring Solenica is situated on a tectonic contact with dolomite marbles and schist 


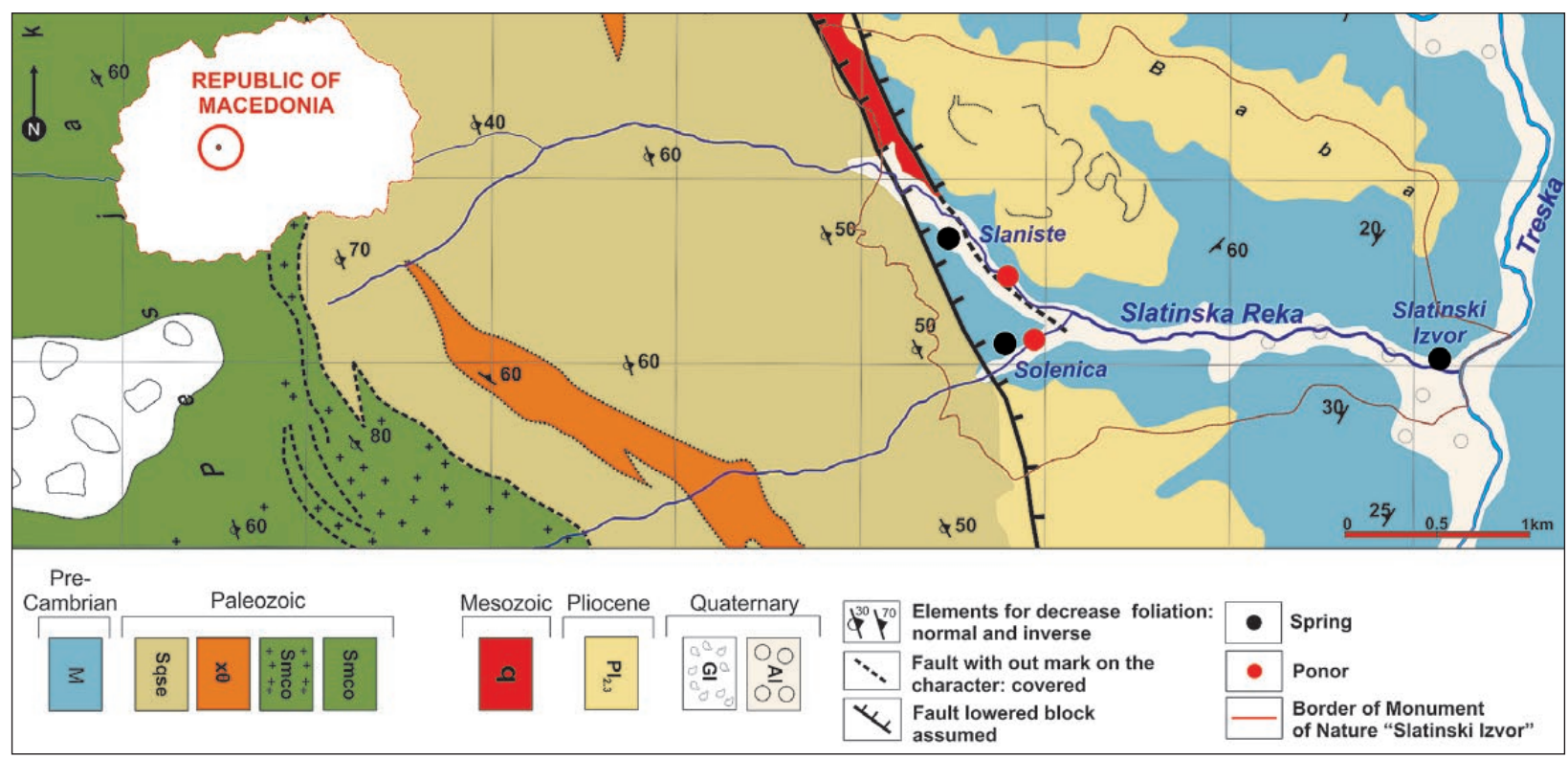

Fig. 1: Hydrogeological map of the study area. Legend: M-dolomite marbles, Sqse-quartz-sericite schists and metasandstones, $x \Theta-$ metarhyolite tuffs, Smco-muscovite-chlorite-quartz schists, Smco-epidote-chlorite-amphibole schists, q-aplitic granite, Pl 2 -Pliocene sediments, Gl-moraines, Al-alluvium.

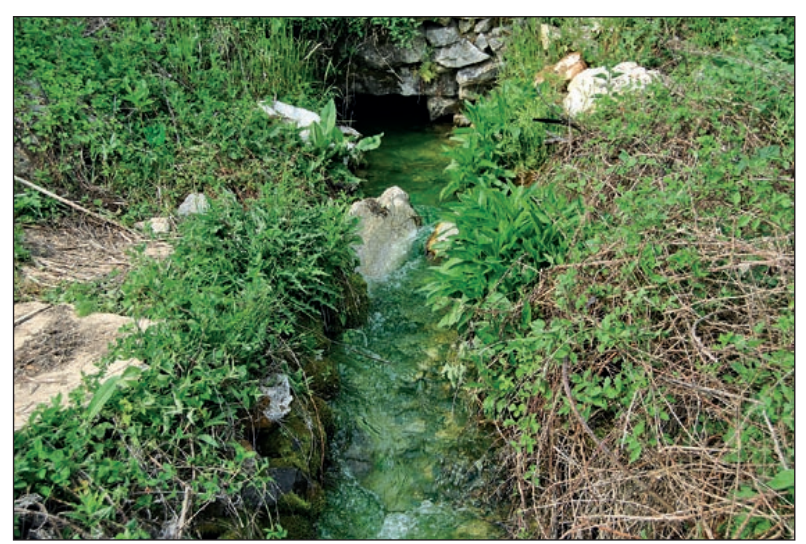

Fig. 2: The spring Slatinski Izvor - the spring is cca $60 \mathrm{~cm}$ wide (Photo: B. Gičevski).

formations (Fig. 3). It is a cold mineral spring. The water is gathered in two small pools that are covered by manmade structure (stone arch covered by soil). This spring never dries out and has low discharges ranging from 0.06 to $0.10 \mathrm{~L} \cdot \mathrm{s}^{-1}$. Thus, the temperature of water depends on

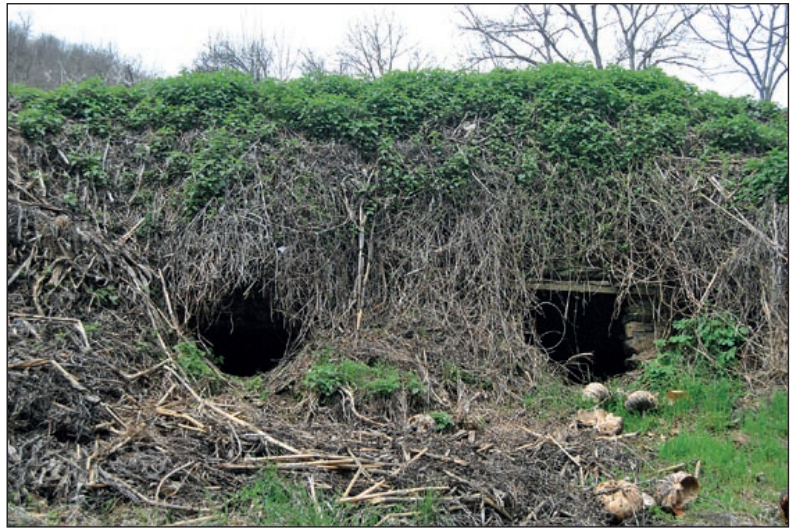

Fig. 3: The spring Solenica - the right hole is cca $70 \mathrm{~cm}$ wide (Photo: B. Gičevski).

the air temperature. The area above the spring is used for agriculture (beans and corn). The spring Slanište is located at the same fault zone as the spring Solenica, and it is captured for water supply.

\section{METHODS}

In order to identify the mineralogical and chemical composition of the rocks which encompass the wider area around the investigated springs, five samples of rock material were taken. The major and minor elemental prop- erties of the rock material were analyzed with an Atomic emission spectroscopy with inductively coupled plasma (AES-ICP), LYBERTY 110 at the University "Goce Delčev" in Štip. The following elements were analyzed: 
oxygen $(\mathrm{O})$, calcium $(\mathrm{Ca})$, magnesium $(\mathrm{Mg})$, iron $(\mathrm{Fe})$, silica $(\mathrm{Si})$, potassium $(\mathrm{K})$, sodium $(\mathrm{Na})$, manganese $(\mathrm{Mn})$, aluminum $(\mathrm{Al})$, titanium $(\mathrm{Ti})$, phosphorus $(\mathrm{P})$, strontium $(\mathrm{Sr})$, barium $(\mathrm{Ba})$, zinc $(\mathrm{Zn})$, chromium $(\mathrm{Cr})$, lead $(\mathrm{Pb})$, vanadium $(\mathrm{V})$, molybdenum $(\mathrm{Mo})$, copper $(\mathrm{Cu})$, cobalt (Co), boron (B), nickel (Ni), cadmium (Cd), arsenic (As) and silver (Ag). The results for oxides of $\mathrm{Ca}, \mathrm{Mg}, \mathrm{K}, \mathrm{Na}$, $\mathrm{Mn}, \mathrm{P}, \mathrm{Fe}, \mathrm{Al}$, Ti and $\mathrm{Si}$ are presented in weight percentage while the rest of the elements in $\mathrm{mg} \cdot \mathrm{kg}^{-1}$.

In order to identify the chemical characteristics of the spring waters, field measurements and laboratory analyses were carried out. These were the first continuous analysis for the both springs. The water samples were collected every month between December 2011-November 2013. A total of 21 water samples were collected from the spring Slatinski Izvor, and 22 from the spring Solenica. Water temperature, $\mathrm{pH}$ and conductivity were measured in-situ at the time of sample collection using the field instrument Lovibond CHECKIT Micro. Samples were collected manually in polyethylene bottles.

The hydrochemical properties were analyzed at the Institute of Biology, Faculty of Natural Sciences and Mathematics, Ss. Cyril and Methodius University in Skopje. All water samples were filtered within 12 hours of collection and analyzed within 3-4 days. Sulphate was determined by photometric method of Dévai et al. (1973) and chlorides by Mohr's method (Škunca-Milovanović et al. 1990). All of the major cations: sodium (Na), potassium $(\mathrm{K})$, calcium $(\mathrm{Ca})$, magnesium $(\mathrm{Mg})$ as well as minor cations and trace elements: copper $(\mathrm{Cu})$, cadmium $(\mathrm{Cd})$, cobalt $(\mathrm{Co})$, lead $(\mathrm{Pb})$, manganese $(\mathrm{Mn})$, zinc $(\mathrm{Zn})$, iron $(\mathrm{Fe})$ were analyzed by wet digestion followed by atomic absorption spectrometry on Agilent $55 \mathrm{Z}$ or graphite furnace Agilent 240Z (Allen 1989). Total phosphorus was determined in the same digested material by the method of Fiske \& Subarow (1925). All of the values are presented in mass concentrations $\left(\mathrm{mg} \cdot \mathrm{L}^{-1}\right) . \mathrm{Ca} /$ $\mathrm{Mg}$ and $\mathrm{Na} / \mathrm{Cl}$ ratios were calculated based on values of respective ions expressed in meq. $\mathrm{L}^{-1}$.

For the interpretation of the chemical analyses, several graphical methods were used. The data were plotted on a trilinear Piper diagram (Piper 1944). The major cations and anions are plotted in milligram per liter $\left(\mathrm{mg} \cdot \mathrm{L}^{-1}\right)$, in each triangle, then the plotting from triangular fields was extended further into the central diamond field. The Piper diagram was used to identify the water composition type and rock types of the aquifer. According to the Piper analysis there are four types of water: waters with temporary hardness (dominant anion is $\mathrm{HCO}_{3}^{-}$), with permanent hardness (other anions dominate), with alkali carbonates and saline waters. The Stiff diagram (Stiff 1951) is a method in which an irregular polygon is constructed from four parallel horizontal axes extending on either side of a vertical zero axis. Cations are plotted on the left side of the zero axis, and anions are plotted on the right side, both in milliequivalents per liter (meq $\left.\cdot \mathrm{L}^{-1}\right)$. Each different pattern represents a different type of water. In the Chadha diagram (Chadha 1999) the difference in milliequivalent percentage between alkaline earth metals $(\mathrm{Ca}+\mathrm{Mg})$ and alkali metals $(\mathrm{Na}+\mathrm{K})$, expressed as percentage reacting values, is plotted on the $\mathrm{X}$-axis, and the difference in milliequivalent percentage between weak acidic anions (carbonate + bicarbonate) and strong acidic anions (chloride + sulphate) is plotted on the Y-axis. The milliequivalent percentage differences between alkaline earths and alkali metals, and between weak acidic anions and strong acidic anions, would plot in one of the four possible sub-fields of the proposed diagram. The square or rectangular field describes the overall character of the water. Using basic cations and anions D’Amore et al. (1983) determined six new parameters for distinguishing water groups based on the geological features of the main reservoir crossed by each water sample. Hydrochemical parameters are marked by letters from A to F:

$$
\begin{aligned}
& \mathrm{A}: \frac{100}{\sum(-)}\left(\mathrm{HCO}_{3}^{-}-\mathrm{SO}_{4}^{2-}\right) \\
& \text { B: } 100\left(\frac{S \mathrm{SO}_{4}^{2-}}{\sum(-)}-\frac{N a^{+}}{\sum(+)}\right) \\
& \text { C: } 100\left(\frac{\mathrm{Na}^{+}}{\sum(+)}-\frac{C l^{-}}{\sum(-)}\right) \\
& \text { D: } 100\left(\frac{\mathrm{Na}^{+}-\mathrm{Mg}^{2+}}{\sum(+)}\right) \\
& \text { E: } 100\left(\frac{\mathrm{Ca}^{2+}+\mathrm{Mg}^{2+}}{\sum(+)}-\frac{\mathrm{HCO}_{3}^{-}}{\sum(-)}\right) \\
& \text { F: } 100\left(\frac{\mathrm{Ca}^{2+}-\mathrm{Na}^{+}-\mathrm{K}^{+}}{\sum(+)}\right)
\end{aligned}
$$

Parameters define the ratio between dissolved species where brackets represent concentrations in meq. $\mathrm{L}^{-1}$, and range from +100 to $-100 \mathrm{meq} \cdot \mathrm{L}^{-1}$. Sum $\Sigma$ represents the sum of cation $(+)$ and anion $(-)$ concentrations. Parameter $\mathrm{A}$ assists in distinguishing between water circulations through calcareous terrains and those occurring in evaporitic rocks; Parameter B discriminates between sulphate-enriched waters circulating in evaporitic terrains and $\mathrm{Na}$-enriched waters that encountered marly, clayey sedimentary terrains; Parameter $\mathrm{C}$ tends to distinguish between waters deriving from 'flysch' or 'volcanites' and those coming from carbonate-evaporitic series or from a regional quartzitic schistose basement; Parameter D indicates waters that have circulated in dolomitized limestone; Parameter E distinguishes between circulations in 
carbonate reservoirs and those in sulphate-bearing reservoirs; Parameter F reveals the increasing $\mathrm{K}^{+}$concentration in the water samples (D'Amore et al. 1983).

The saturation indexes (SI) of minerals (anhydrite, aragonite, calcite, dolomite, gypsum and halite) available in the aquifer were calculated using WATEQ4F comput- er program (Plummer et al. 1976). If the water is exactly saturated with the dissolving mineral, saturation index equals to zero. Positive values of saturation index indicate saturation, and negative ones indicate undersaturation.

\section{RESULTS AND DISCUSION}

\section{MINERALOGICAL CHARACTERISTICS}

Carbonate rocks from the analyzed area are represented by dolomite marbles. They are homogeneous, and their colour ranges from light grey to bright white. Their structure is granoblastic and their texture massive. The rock is composed of dolomite grains of $0.1-0.4 \mathrm{~mm}$ in size, and also contains grains of calcite, quartz and muscovite (Dumurdzanov et al. 1979). The chemical composition of the carbonate rocks (Tab. 1) showed that $\mathrm{CaO}$ and $\mathrm{MgO}$ are the dominantly represented. B, Sr and V are the dominant trace elements in all rock samples.

The schists are para-metamorphic rocks with grey, yellow and green colour. The structure is lepido-granoblastic, and the texture is schistose. It is composed of: quartz, chlorite, amphibole, albite, sericite, muscovite, magnetite (Dumurdzanov et al. 1979). Both schist samples which were analysed were taken in the area between the villages Slatina and Krušje. The chemical composition of these rocks is represented in Table $1 . \mathrm{SiO}_{2}$ is dominant in both schist samples, then follow $\mathrm{Al}_{2} \mathrm{O}_{3}, \mathrm{FeO}$ and $\mathrm{Na}_{2} \mathrm{O}$. On the first sample, the trace elements (Tab. 1) B, Sr, Zn, $\mathrm{V}, \mathrm{Pb}, \mathrm{Cr}$ are represented in higher quantity, whereas the elements $\mathrm{B}, \mathrm{Zn}, \mathrm{Ba}, \mathrm{Sr}, \mathrm{Pb}, \mathrm{V}, \mathrm{Cu}$ are represented in the second sample.

\section{GENERAL HYDROCHEMICAL COMPOSITION OF THE SPRING WATERS}

The hydrochemical properties of the springs Slatinski Izvor and Solenica are presented in Table 2. The Slatinski Izvor spring showed small temperature variations. The average temperature was $9.32^{\circ} \mathrm{C}$ oscillating in an interval from $8^{\circ} \mathrm{C}$ to $10.2^{\circ} \mathrm{C}$. The Solenica spring showed continuous seasonal fluctuations. Average temperature was $9.6^{\circ} \mathrm{C}$ oscillating in an interval from $0^{\circ} \mathrm{C}$ to $16^{\circ} \mathrm{C}$. The $\mathrm{pH}$ values showed that the springs belong to the water group with alkaline reaction, oscillating in an interval from 7.0 to 8.2 (Slatinski Izvor) and between 7.6 and 8.4 (Solenica). The mean values of EC of waters from Slatinski Izvor and Solenica were $256.90 \mu \mathrm{S} \cdot \mathrm{cm}^{-1}$ and $7310.45 \mu \mathrm{S} \cdot \mathrm{cm}^{-1}$, respectively. The mean value of total dissolved solids (TDS) was $164.41 \mathrm{mg} \cdot \mathrm{L}^{-1}$ (Slatinski Izvor) and $4687.69 \mathrm{mg} \cdot \mathrm{L}^{-1}$
Tab. 1: Chemical composition and trace elements of the rock samples by AES-ICP (K2-dolomite marble in front of the entrance into the Slatinski Izvor cave, K3-dolomite marble-Baba Hill, SiK1-marble from the cave Slatinski Izvor, K1A, K1B-schists between villages Slatina and Krušje)

\begin{tabular}{l|c|c|c|c|c}
\hline & $K 2$ & $K 3$ & $S i K 1$ & $K 1 A$ & $K 1 B$ \\
\hline $\mathrm{SiO}_{2}(\%)$ & 6.98 & 0.28 & 0.00 & 75.42 & 75.02 \\
\hline $\mathrm{Al}_{2} \mathrm{O}_{3}(\%)$ & 0.51 & 0.24 & 0.26 & 11.29 & 12.08 \\
\hline $\mathrm{CaO}(\%)$ & 28.0 & 29.7 & 32.2 & 0.83 & 0.65 \\
\hline $\mathrm{MgO}(\%)$ & 18.70 & 23.18 & 23.1 & 0.99 & 0.71 \\
\hline $\mathrm{Na}_{2} \mathrm{O}(\%)$ & 0.26 & 0.27 & 0.29 & 3.21 & 3.55 \\
\hline $\mathrm{K}_{2} \mathrm{O}(\%)$ & 0.12 & 0.07 & 0.05 & 1.82 & 1.65 \\
\hline $\mathrm{FeO}(\%)$ & 0.23 & 0.05 & 0.04 & 3.95 & 3.40 \\
\hline $\mathrm{MnO}(\%)$ & 0.01 & 0.00 & 0.00 & 0.07 & 0.05 \\
\hline $\mathrm{P}_{2} \mathrm{O}_{5}(\%)$ & 0.02 & 0.01 & 0.01 & 0.09 & 0.09 \\
\hline $\mathrm{TiO} \mathrm{O}_{2}(\%)$ & 0.02 & 0.00 & 0.00030 & 0.40 & 0.68 \\
\hline $\mathrm{Ashing} \mathrm{loss}(\%)$ & 45.1 & 46.1 & 43.8 & 1.54 & 1.63 \\
\hline $\mathrm{Total}$ & 99.95 & 99.95 & 99.78 & 99.61 & 99.52 \\
\hline $\mathrm{Sr}(\mathrm{mg} / \mathrm{kg})$ & 81.65 & 108.37 & 82.04 & 165.42 & 154.18 \\
\hline $\mathrm{Ba}(\mathrm{mg} / \mathrm{kg})$ & 10.09 & 5.05 & 3.96 & 10.09 & 248.33 \\
\hline $\mathrm{Zn}(\mathrm{mg} / \mathrm{kg})$ & 7.65 & 3.00 & 2.12 & 143.58 & 286.77 \\
\hline $\mathrm{Cr}(\mathrm{mg} / \mathrm{kg})$ & 1.73 & 1.04 & 1.81 & 28.30 & 32.46 \\
\hline $\mathrm{Pb}(\mathrm{mg} / \mathrm{kg})$ & 2.60 & 3.47 & 1.17 & 34.09 & 86.98 \\
\hline $\mathrm{V}(\mathrm{mg} / \mathrm{kg})$ & 17.96 & 15.00 & 14.10 & 43.10 & 74.21 \\
\hline $\mathrm{Mo}(\mathrm{mg} / \mathrm{kg})$ & 6.96 & 4.56 & 7.10 & 10.26 & 12.96 \\
\hline $\mathrm{Cu}(\mathrm{mg} / \mathrm{kg})$ & 2.19 & 1.86 & $<2$ & 12.96 & 24.15 \\
\hline $\mathrm{Co}(\mathrm{mg} / \mathrm{kg})$ & $<2$ & $<2$ & $<2$ & 7.26 & 6.26 \\
\hline $\mathrm{B}(\mathrm{mg} / \mathrm{kg})$ & 658.98 & 796.86 & 659.05 & 463.92 & 338.98 \\
\hline $\mathrm{Ni}(\mathrm{mg} / \mathrm{kg})$ & 3.13 & $<2$ & $<2$ & 10.99 & 12.82 \\
\hline $\mathrm{Cd}(\mathrm{mg} / \mathrm{kg})$ & $<1$ & $<1$ & $<1$ & $<1$ & 1.82 \\
\hline $\mathrm{As}(\mathrm{mg} / \mathrm{kg})$ & $<2$ & $<2$ & 1.93 & 6.83 & 5.52 \\
\hline $\mathrm{Ag}(\mathrm{mg} / \mathrm{kg})$ & $<2$ & $<2$ & 0.26 & $<2$ & $<2$ \\
\hline & & & & & \\
\hline
\end{tabular}

(Solenica). EC and TDS of the Slatinski Izvor spring had lower values which may be attributed to the short residence time of the water in the karst aquifer, whereas the high values of the Solenica spring mean high concentration of dissolved solids like chloride, carbonates, bicarbonates and sulphate, and longer residence time of the water in the aquifer. 


\begin{tabular}{|c|c|c|}
\hline & $\begin{array}{c}\text { Slatinski Izvor } \\
(n=21)\end{array}$ & $\begin{array}{c}\text { Solenica } \\
(n=22)\end{array}$ \\
\hline $\begin{array}{l}T\left({ }^{\circ} \mathrm{C}\right) \\
\text { Range } \\
\text { Mean } \\
\mathrm{CV} \\
\end{array}$ & $\begin{array}{c}8.0-10.2 \\
9.32 \\
0.07 \\
\end{array}$ & $\begin{array}{c}0.0-16.0 \\
9.6 \\
0.52 \\
\end{array}$ \\
\hline $\begin{array}{l}\text { pH } \\
\text { Range } \\
\text { Mean } \\
\text { CV }\end{array}$ & $\begin{array}{c}7.0-8.2 \\
7.9 \\
0.04\end{array}$ & $\begin{array}{c}7.6-8.4 \\
7.9 \\
0.02 \\
\end{array}$ \\
\hline $\begin{array}{l}E C\left(\mu S \cdot \mathrm{cm}^{-1}\right) \\
\text { Range } \\
\text { Mean } \\
\text { CV }\end{array}$ & $\begin{array}{c}200-410 \\
256.90 \\
0.21 \\
\end{array}$ & $\begin{array}{c}3000-11500 \\
7310.45 \\
0.27 \\
\end{array}$ \\
\hline $\begin{array}{l}\text { TDS }\left(m g \cdot L^{-1}\right) \\
\text { Range } \\
\text { Mean } \\
\text { CV }\end{array}$ & $\begin{array}{c}128-262.4 \\
164.41 \\
0.21 \\
\end{array}$ & $\begin{array}{c}1920-7360 \\
4687.69 \\
0.27 \\
\end{array}$ \\
\hline $\begin{array}{l}\mathrm{Ca}^{2+}\left(m g \cdot L^{-1}\right) \\
\text { Range } \\
\text { Mean } \\
\mathrm{CV}\end{array}$ & $\begin{array}{c}10.64-39.519 \\
25.89 \\
0.3\end{array}$ & $\begin{array}{c}75.62-326.75 \\
188.17 \\
0.3 \\
\end{array}$ \\
\hline $\begin{array}{l}\mathrm{Mg}^{2+}\left(m g \cdot L^{-1}\right) \\
\text { Range } \\
\text { Mean } \\
\mathrm{CV}\end{array}$ & $\begin{array}{c}6.18-13.81 \\
9.70 \\
0.2 \\
\end{array}$ & $\begin{array}{c}2.62-17.22 \\
7.85 \\
0.5 \\
\end{array}$ \\
\hline $\begin{array}{l}\mathrm{Cl}^{-}\left(m g \cdot L^{-1}\right) \\
\text { Range } \\
\text { Mean } \\
\mathrm{CV}\end{array}$ & $\begin{array}{c}8.0-21.60 \\
14.10 \\
0.28\end{array}$ & $\begin{array}{c}3000.0-16700.0 \\
6476.36 \\
0.52 \\
\end{array}$ \\
\hline $\begin{array}{l}\mathrm{Na}^{+}\left(m g \cdot L^{-1}\right) \\
\text { Range } \\
\text { Mean } \\
\mathrm{CV}\end{array}$ & $\begin{array}{c}2.59-6.22 \\
3.86 \\
0.30\end{array}$ & $\begin{array}{c}139.04-2452.50 \\
1141.76 \\
0.45\end{array}$ \\
\hline $\begin{array}{l}K^{+}\left(m g \cdot L^{-1}\right) \\
\text { Range } \\
\text { Mean } \\
\mathrm{CV}\end{array}$ & $\begin{array}{c}0.66-1.16 \\
0.86 \\
2.06\end{array}$ & $\begin{array}{c}2.72-14.03 \\
7.73 \\
0.38 \\
\end{array}$ \\
\hline $\begin{array}{l}\mathrm{SO}_{4}^{2-}\left(m g \cdot L^{-1}\right) \\
\text { Range } \\
\text { Mean } \\
\mathrm{CV}\end{array}$ & $\begin{array}{c}12.77-45.20 \\
28.58 \\
0.27 \\
\end{array}$ & $\begin{array}{c}65.04-298.22 \\
155.04 \\
0.43 \\
\end{array}$ \\
\hline $\begin{array}{l}\mathrm{HCO}_{3}^{-}\left(m g \cdot \mathrm{L}^{-1}\right) \\
\text { Range } \\
\text { Mean } \\
\mathrm{CV}\end{array}$ & $\begin{array}{c}176.9-244.0 \\
218.54 \\
0.09 \\
\end{array}$ & $\begin{array}{c}122.0-201.3 \\
170.95 \\
0.12 \\
\end{array}$ \\
\hline $\begin{array}{l}\mathrm{NO}_{3}^{-}\left(m g \cdot \mathrm{L}^{-1}\right) \\
\text { Range } \\
\text { Mean } \\
\mathrm{CV}\end{array}$ & $\begin{array}{c}0.04-2.24 \\
0.79 \\
1.79 \\
\end{array}$ & $\begin{array}{c}1.32-11.82 \\
5.33 \\
0.57\end{array}$ \\
\hline $\begin{array}{l}\mathrm{NO}_{2}^{-}\left(m g \cdot \mathrm{L}^{-1}\right) \\
\text { Range } \\
\text { Mean } \\
\mathrm{CV}\end{array}$ & $\begin{array}{c}0.00-0.14 \\
0.02 \\
/\end{array}$ & $\begin{array}{c}0.01-1.53 \\
0.18 \\
4.62 \\
\end{array}$ \\
\hline $\begin{array}{l}\mathrm{NH}_{4}^{+}\left(m g \cdot \mathrm{L}^{-1}\right) \\
\text { Range } \\
\text { Mean } \\
\mathrm{CV}\end{array}$ & $\begin{array}{c}0.00-0.58 \\
0.21 \\
/\end{array}$ & $\begin{array}{c}0.00-28.79 \\
6.96 \\
1.34 \\
\end{array}$ \\
\hline
\end{tabular}

Tab. 2: Hydrochemical data from the springs Slatinski Izvor and Solenica. December 2011 to November 2013. CV-coefficient of variation, TDS - total dissolved solids, $n$ - number of water samples.

Slatinski Izvor spring had hard water $\left(>120 \mathrm{mg} \mathrm{L}^{-1}\right)$ according to the classification of Ford and Williams (2007) based on TDS while spring Solenica had brackish water (1000-10 $000 \mathrm{mg} \mathrm{L}^{-1}$ ).

Major ions in the Slatinski Izvor spring were dominantly $\mathrm{Ca}^{2+}>\mathrm{Mg}^{2+}>\mathrm{Na}^{+}$for the cations and $\mathrm{HCO}_{3}{ }^{-}>\mathrm{SO}_{4}{ }^{2-}$ $>\mathrm{Cl}^{-}$for the anions (Tab. 3). The major ions in the Solenica spring were $\mathrm{Na}^{+}>\mathrm{Ca}^{2+}>\mathrm{Mg}^{2+}$ for the cations and $\mathrm{Cl}^{-}>\mathrm{HCO}_{3}^{-}>\mathrm{SO}_{4}^{2-}$ for the anions (Tab. 3). $\mathrm{HCO}_{3}^{-}$and $\mathrm{SO}_{4}{ }^{2-}$ were dominant dissolved species in the spring water of Slatinski Izvor which indicate the predominant carbonate and sulphate rocks in the aquifer. $\mathrm{Cl}^{-}$and $\mathrm{Na}^{+}$were dominant dissolved species in the water of the Solenica spring giving the water salty taste. The mean values of the chemical parameters of the Slatinski Izvor spring were: $\mathrm{Ca}^{2+}=25.89 \mathrm{mg} \cdot \mathrm{L}^{-1}, \mathrm{Mg}^{2+}=9.7 \mathrm{mg} \cdot \mathrm{L}^{-1}, \mathrm{Cl}^{-}=14.1 \mathrm{mg} \cdot \mathrm{L}^{-1}$, $\mathrm{Na}^{+}=3.86 \mathrm{mg} \cdot \mathrm{L}^{-1}, \mathrm{~K}^{+}=0.86 \mathrm{mg} \cdot \mathrm{L}^{-1}, \mathrm{SO}_{4}^{2-}=28.58 \mathrm{mg} \cdot \mathrm{L}^{-1}$, $\mathrm{HCO}_{3}{ }^{-}=218.54 \mathrm{mg} \cdot \mathrm{L}^{-1}$. The mean values of the same parameters for the spring Solenica were $\mathrm{Ca}^{2+}=188.17$ $\mathrm{mg} \cdot \mathrm{L}^{-1}, \quad \mathrm{Mg}^{2+}=7.85 \quad \mathrm{mg} \cdot \mathrm{L}^{-1}, \quad \mathrm{Cl}=6476.36 \mathrm{mg} \cdot \mathrm{L}^{-1}$, $\mathrm{Na}^{+}=1141.76 \mathrm{mg} \cdot \mathrm{L}^{-1}, \mathrm{~K}^{+}=7.73 \mathrm{mg} \cdot \mathrm{L}^{-1}, \mathrm{SO}_{4}^{2-}=155.04 \mathrm{mg} \cdot \mathrm{L}^{-1}$, $\mathrm{HCO}_{3}^{-}=170.95 \mathrm{mg} \cdot \mathrm{L}^{-1}$, respectively.

The average total hardness of the water samples of the springs Slatinski Izvor and Solenica were 104.03 and $501.17 \mathrm{mg} \cdot \mathrm{L}^{-1}$, respectively. According to Sawyer and McCarty's (1967) classification, the spring Slatinski Izvor had moderately hard $\left(75-150 \mathrm{mg} \cdot \mathrm{L}^{-1}\right)$, whereas the spring Solenica belongs to very hard class $\left(>300 \mathrm{mg} \cdot \mathrm{L}^{-1}\right)$.

The $\mathrm{Ca} / \mathrm{Mg}$ ratio provides information on the rock type through which the groundwater has passed. The values of $\mathrm{Ca} / \mathrm{Mg}$ index of Slatinski Izvor were 2.0 for the first year and 1.52 for the second year. This ratio indicates a dolomitic limestone or mixed limestone-dolomite sequence (White 1999). This parameter for the spring Solenica was 14.84 for the first year, and 20.34 for the second year. The ratio indicates a long residence time of the groundwater in the aquifer which enables the dissolution of calcite fractions that are dispersed throughout the aquifer.

All water samples of the Solenica spring showed $\mathrm{Na} / \mathrm{Cl}$ ratio lower than 0.7. According to Melloul and Goldenberg (1998) this water type represents "pockets" of water which are slightly to highly saline, and originating from ancient seawater.

\section{WATER QUALITY}

The water from the Slatinski Izvor spring displayed good quality during the investigation period, especially 


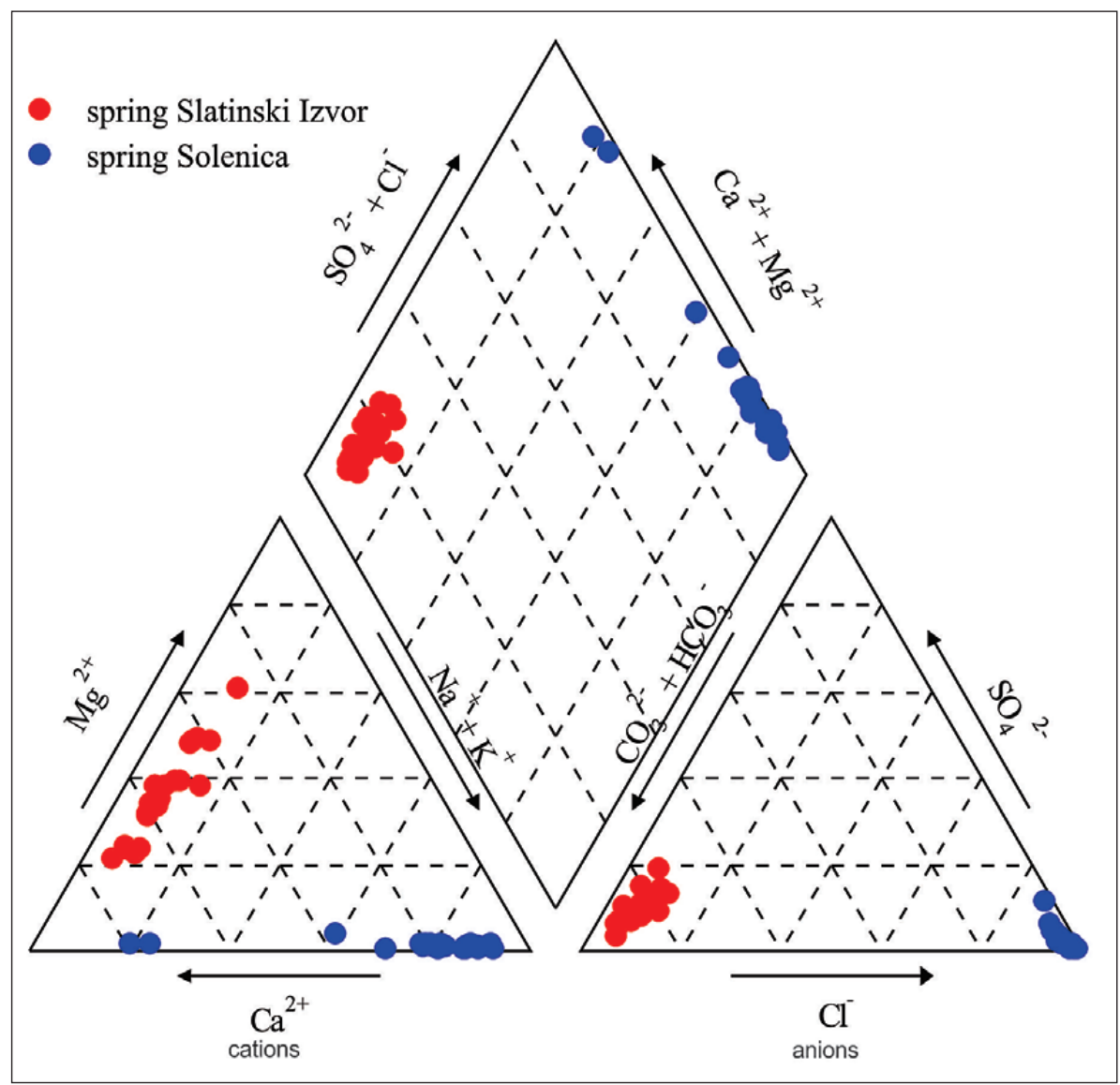

Fig. 4: Piper trilinear diagram of waters of springs Slatinski Izvor and Solenica

regarding the low nitrate $\left(0.79 \mathrm{mg} \cdot \mathrm{L}^{-1}\right)$, nitrite $(0.02$ $\left.\mathrm{mg} \cdot \mathrm{L}^{-1}\right)$, ammonium $\left(0.21 \mathrm{mg} \cdot \mathrm{L}^{-1}\right)$, and phosphate $(0.01$ $\left.\mathrm{mg} \cdot \mathrm{L}^{-1}\right)$ concentrations. This is due to the low human impact and probably due to the well preserved natural communities (forests and grasslands) in the catchment area. The Slatinski Izvor spring is suitable for water supply. Regarding the limits in Macedonian Regulations of Natural Mineral Water (Official gazette of the Republic of Macedonia, No. 32/2006) the water from the Solenica spring is not suitable for drinking because of the high mean values of nitrate $\left(5.33 \mathrm{mg} \cdot \mathrm{L}^{-1}\right)$, nitrite $(0.18$ $\left.\mathrm{mg} \cdot \mathrm{L}^{-1}\right)$, ammonium $\left(6.96 \mathrm{mg} \cdot \mathrm{L}^{-1}\right)$ and phosphate $(0.54$ $\left.\mathrm{mg} \cdot \mathrm{L}^{-1}\right)$ concentrations. The higher values are results of the waste water from the part of the houses in the village Slatina and because of the agricultural fields above the spring, especially during the summer and autumn periods.

\section{GRAPHO-ANALYTICAL METHODS}

All water samples of the springs Slatinski Izvor and Solenica showed different characteristics.

Cation and anion concentrations are presented on Piper diagram in milligram per litre $\left(\mathrm{mg} \cdot \mathrm{L}^{-1}\right)$ (Fig. 4). Water of the spring Slatinski Izvor is plotted near the left corner of the diamond which showed that the water is reach in $\mathrm{Ca}^{2+}, \mathrm{Mg}^{2+}$ and $\mathrm{HCO}_{3}^{-}$and is the region of water of temporary hardness. The aquifer is composed of dolomite. The chemical composition of the spring is characterized by $\mathrm{Ca}-\mathrm{HCO}_{3}$ type which is typical of shallow and fresh waters. Twenty water samples of the spring Solenica lying near the right corner of the diamond show that the water is salty and rich in $\mathrm{Cl}^{-}$and $\mathrm{SO}_{4}^{2+}$ as well as $\mathrm{Na}^{+}$ and $\mathrm{K}^{+}$. The aquifer is composed of brine. The chemical composition of the spring is characterized by $\mathrm{Na}-\mathrm{Cl}$ type which is typical of deep ancient ground waters. Only two water samples, taken on April 2012 and March 2013, are plotted at the top of the diamond. This shows that the water is high in both $\mathrm{Ca}^{2+}+\mathrm{Mg}^{2+}$ and $\mathrm{Cl}^{-}+\mathrm{SO}_{4}^{2+}$, and has permanent hardness. The chemical composition of the water is $\mathrm{Ca}-\mathrm{SO}_{4}$ type.

The water of the Solenica spring contains high concentrations of $\mathrm{Na}$ and $\mathrm{Cl}$ ions which give very high values for conductivity. Similar chemical characteristics have been evidenced in another (geographically close) brine spring Slansko which is situated on the same tectonic fault. Kotevski (1987) reported dominance of chlorides and sodium ions in the Slansko spring and proved its deep origin. There is third brine spring on this tectonic fault (Slanište), but no information on the water chemistry is available. 

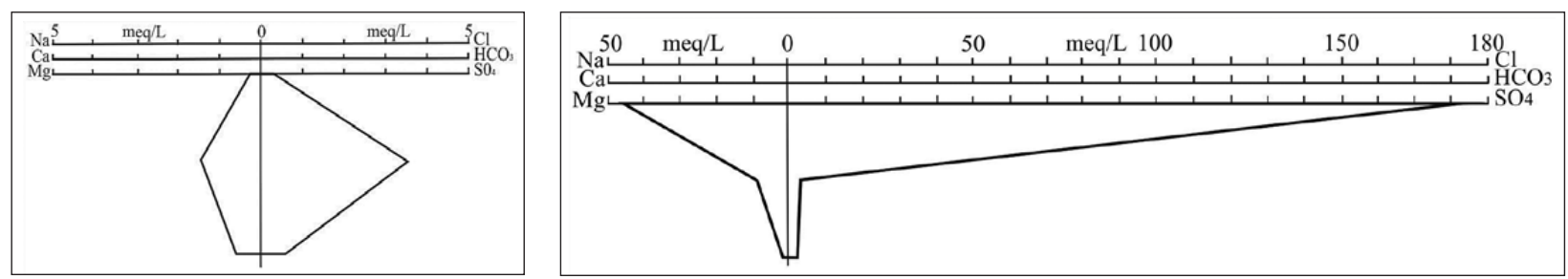

Fig. 5: Stiff diagram for the springs Slatinski Izvor (left) and Solenica (right)

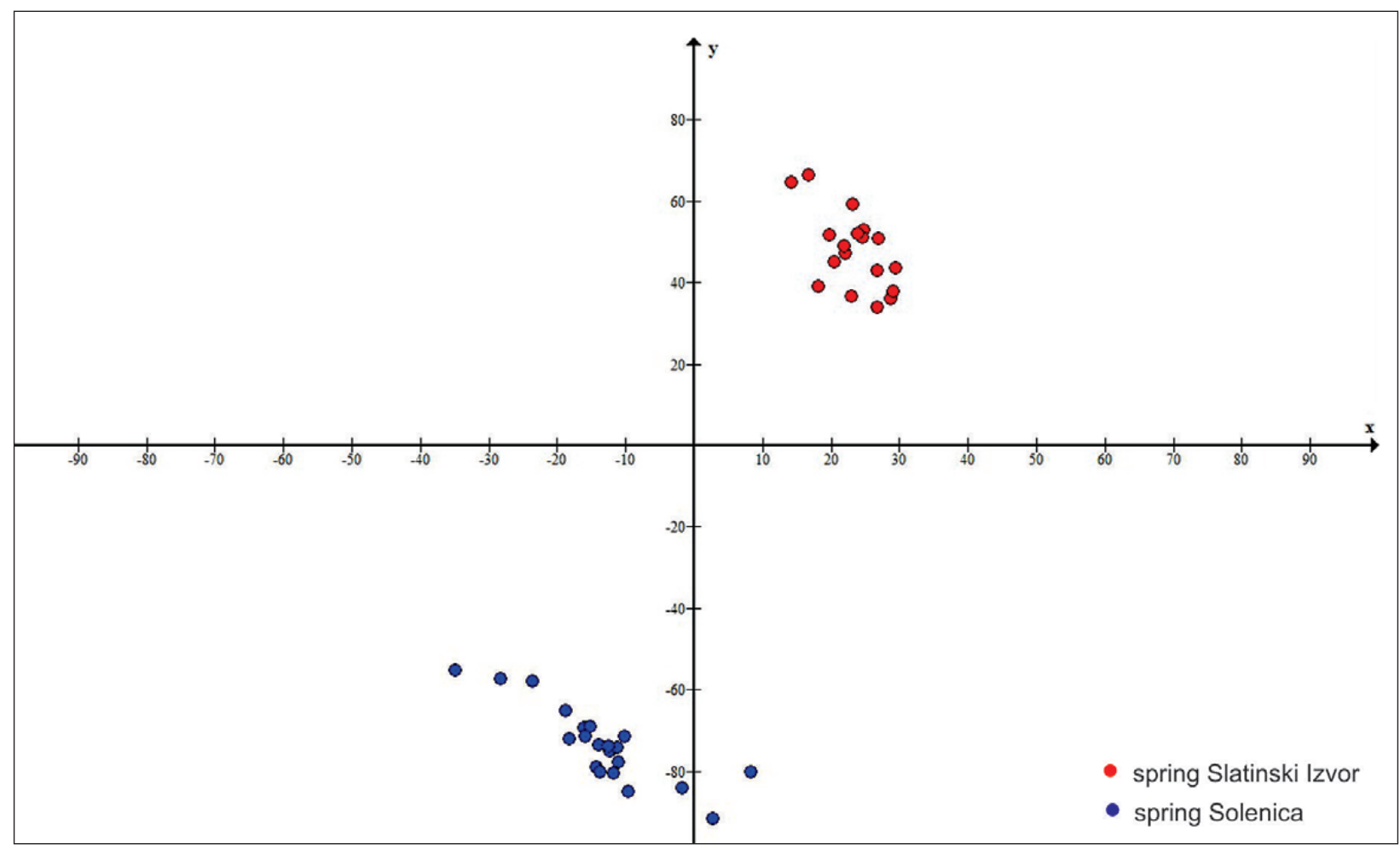

Fig. 6: Chadha diagram

The dominant influence of limestone in the water of the Slatinski Izvor spring and the dominance of chloride and $\mathrm{Na}$ in the water of the Solenica spring are presented on Stiff diagram (Fig. 5).

All water samples of the springs are plotted on Chadha diagram (Fig. 6). Water from the Slatinski Izvor spring fall in the $5^{\text {th }}$ sub-field, which indicates that alkaline earths $\left(\mathrm{Ca}^{2+}+\mathrm{Mg}^{2+}\right)$ and weak acidic anions $\left(\mathrm{CO}_{3}^{2+}+\right.$ $\left.\mathrm{HCO}_{3}^{-}\right)$exceed both alkali metals $\left(\mathrm{Na}^{+}+\mathrm{K}^{+}\right)$and strong acidic anions $\left(\mathrm{Cl}^{-}+\mathrm{SO}_{4}^{2-}\right)$, respectively. Such water had temporary hardness. Twenty water samples of the Solenica spring fall in the $7^{\text {th }}$ sub-field of Chadha diagram. The alkali metals $\left(\mathrm{Na}^{+}+\mathrm{K}^{+}\right)$exceed alkaline earths $\left(\mathrm{Ca}^{2+}+\right.$ $\left.\mathrm{Mg}^{2+}\right)$ and strong acidic anions $\left(\mathrm{Cl}^{-}+\mathrm{SO}_{4}^{2-}\right)$ exceed weak acidic anions $\left(\mathrm{CO}_{3}^{2-}+\mathrm{HCO}_{3}^{-}\right)$. Such water generally creates salinity problems both in irrigation and drinking uses (Chadha 1999). Two water samples, taken on April 2012 and March 2013, fall in the $6^{\text {th }}$ sub-field. This in- dicates that alkaline earths $\left(\mathrm{Ca}^{2+}+\mathrm{Mg}^{2+}\right)$ exceed alkali metals $\left(\mathrm{Na}^{+}+\mathrm{K}^{+}\right)$and strong acidic anions $\left(\mathrm{Cl}^{-}+\mathrm{SO}_{4}^{2-}\right)$ exceed weak acidic anions $\left(\mathrm{CO}_{3}^{2-}+\mathrm{HCO}_{3}^{-}\right)$. This water samples had permanent hardness, and represent $\mathrm{Cl}^{-}-$ dominant $\mathrm{Ca}^{2+}-\mathrm{Mg}^{2+}$ type water.

The calculated values of the parameters A-F for the water samples have been plotted in rectangular D'Amore diagrams (Fig. 7). The spring Slatinski Izvor belongs to D'Amore $\beta$ type which is represented by typical calcium hydrogencarbonate type of water. The high value of the A parameter points out a water circulation within carbonate terrains. The low value of the B parameter points out that the water is not in contact with clay sediments. The negative value of the $\mathrm{C}$ parameter points out that the water is coming from carbonate or quartzitic basement. The negative value of the $\mathrm{D}$ parameter points out the water circulation within dolomite limestone. The low value of the E parameter points out that the water circulates 


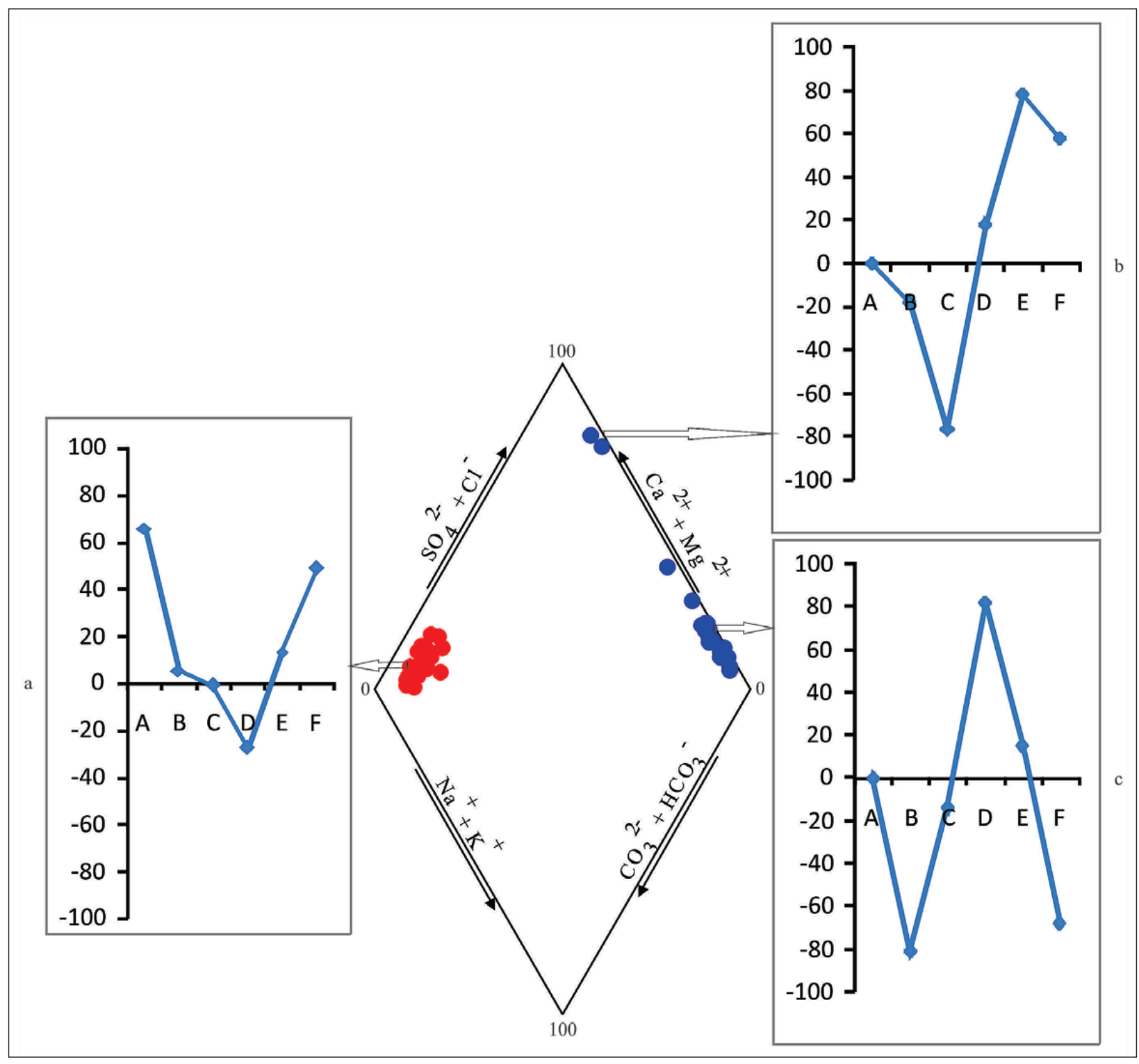

Fig. 7: D’Amore rectangular diagrams for the springs Slatinski Izvor and Solenica (a-Slatinski Izvor, 2-years average, b-Solenica, only samples from IV.2012 and III.2013, c-Solenica, the rest of the samples)

through rock that contains sulphates. The high value of the $\mathrm{F}$ parameter points out that the $\mathrm{Ca}$ concentration is dominantly represented in relation to $\mathrm{Na}$ and $\mathrm{K}$. The spring Solenica belongs to $\gamma$ type which is characterized by $\mathrm{NaCl}$ type water and very deep circulation. The negative value of the A parameter points out that water is in contact with evaporite rocks. The negative value of the B parameter points out $\mathrm{Na}$ enriched water that encountered clay sediments. The negative value of the $C$ parameter points out that the water is coming from evaporitic series or quartzitic schistose basement. The high value of the $\mathrm{D}$ parameter points out that the influence of the dolomitized limestone on the water is low. The value of the E parameter points out water movement through rocks that contain sulphates. The negative value of the $\mathrm{F}$ parameter points out that $\mathrm{Na}$ and $\mathrm{K}$ concentration in the water is higher in relation to Ca concentration. Only two water samples (taken on April 2012 and March 2013) have different values of the parameters A-F. The negative value of the $\mathrm{C}$ parameter points out that the water is coming from carbonate-evaporitic series or quartzitic schistose basement. The value of the $\mathrm{D}$ parameter is smaller which shows that the influence of dolomitized limestone is greater than the others water samples. The value of the E parameter points out the impact of the carbonate rocks. The high value of the $\mathrm{F}$ parameter points out that $\mathrm{Ca}$ concentration is significantly higher in relation to $\mathrm{Na}$ and $\mathrm{K}$ concentration. All abovementioned parameters 
are typical of waters formed in karst aquifers. The value of the B parameter shows that the $\mathrm{Na}$ concentration is lower than other water samples, nevertheless the water in its flow is in contact with clay sediments.

\section{TRACE ELEMENTS}

In our present study eight minor and trace elements $(\mathrm{Cu}$, $\mathrm{Cd}, \mathrm{Co}, \mathrm{Pb}, \mathrm{Mn}, \mathrm{Zn}, \mathrm{Fe}, \mathrm{P}$ ) were analyzed (Tab. 3 ). The concentrations of trace elements in spring waters depend on aquifer mineralogy and on chemical rock-water interactions. Their concentrations in the both springs are low and they are not a significant contaminant of the springs. The highest concentration had $\mathrm{Cu}$, which with $\mathrm{Mn}$, and $\mathrm{Cd}$ can be derived from dissolution of carbonates and oxidation of sulphides, Cd from phosphates (Kilchmann et al. 2004). Low concentrations of $\mathrm{Pb}$ were detected during the rain period of the year which shows that most of the $\mathrm{Pb}$ is derived from the atmosphere. Iodine $\left(\mathrm{I}^{-}\right)$was not a subject of our observation, but it was detected in the spring Solenica ( $5 \mathrm{mg} \cdot \mathrm{L}^{-1}$ ) by Kotevski (1987). It can be attributed to the decomposition of fossil organic matter (Kilchmann et al. 2004) and to the sedimentary origin.

Tab. 3: Trace elements in the water samples.

\begin{tabular}{l|l|l}
\hline \multirow{2}{*}{} & \multicolumn{2}{|l}{ Concentration range $\left(\mu \mathrm{g} \cdot \mathrm{L}^{-1}\right)$} \\
\cline { 2 - 3 } & Slatinski Izvor & Solenica \\
\hline $\mathrm{Cu}$ & $1.438-9.750$ & $4.255-38.750$ \\
\hline $\mathrm{Cd}$ & $\mathrm{nd}-0.305$ & $\mathrm{nd}-0.499$ \\
\hline $\mathrm{Co}$ & $\mathrm{nd}-0.242$ & $0.00-13.354$ \\
\hline $\mathrm{Pb}$ & $\mathrm{nd}-0.267$ & $\mathrm{nd}-0.610$ \\
\hline $\mathrm{Mn}$ & $0.000-0.019$ & $0.007-0.264$ \\
\hline $\mathrm{Zn}$ & $0.002-0.026$ & $0.007-0.060$ \\
\hline $\mathrm{Fe}$ & $0.018-0.631$ & $0.033-0.834$ \\
\hline $\mathrm{P}$ & $0.000-0.075$ & $0.002-3.622$ \\
\hline
\end{tabular}

\section{SATURATION INDICES}

Saturation indices of the water samples are given in Table 4. Water samples of the Slatinski Izvor spring were generally undersaturated or slightly saturated with respect to aragonite, calcite and dolomite. All water samples of the Solenica spring were generally undersaturated or slightly saturated with respect to aragonite. Undersaturation occurred in 19 water samples with respect to dolomite, whereas three samples (March 2013, September 2013 and November 2013) were slightly saturated with respect to dolomite. All water samples were slightly saturated with respect to calcite, except for two water samples (December 2011, and November 2012) were undersaturated with respect to calcite.
Tab. 4: Saturation indices of the water samples.

\begin{tabular}{|c|c|c|c|}
\hline $\begin{array}{l}\text { Date of } \\
\text { sampling }\end{array}$ & Calcite & Dolomite & Aragonite \\
\hline \multicolumn{4}{|c|}{ Sampling point: spring Slatinski Izvor } \\
\hline 04.12 .2011 & -0.190 & -0.776 & -0.346 \\
\hline 08.01 .2012 & -0.004 & -0.092 & -0.160 \\
\hline 12.02 .2012 & -0.158 & -0.582 & -0.315 \\
\hline 24.03 .2012 & 0.242 & -0.154 & 0.085 \\
\hline 15.04 .2012 & 0.282 & -0.050 & 0.126 \\
\hline 06.05 .2012 & -0.079 & -0.840 & -0.235 \\
\hline 22.06 .2012 & -0.885 & -2.153 & -1.041 \\
\hline 21.07 .2012 & -0.118 & -0.043 & -0.273 \\
\hline 23.11 .2012 & -0.670 & -1.927 & -0.825 \\
\hline 15.12 .2012 & 0.381 & 0.129 & 0.225 \\
\hline 07.01 .2013 & 0.240 & 0.034 & 0.083 \\
\hline 10.02 .2013 & 0.124 & -0.022 & -0.032 \\
\hline 17.03.2013 & 0.275 & 0.240 & 0.119 \\
\hline 30.04 .2013 & 0.146 & -0.010 & -0.009 \\
\hline 06.05 .2013 & -0.253 & -0.817 & -0.408 \\
\hline 09.06 .2013 & 0.024 & -0.385 & -0.131 \\
\hline 18.07 .2013 & -0.126 & -0.339 & -0.281 \\
\hline 01.08 .2013 & 0.063 & 0.025 & -0.092 \\
\hline 15.09 .2013 & -0.212 & -0.473 & -0.367 \\
\hline 20.10 .2013 & 0.181 & 0.106 & 0.025 \\
\hline 08.11 .2013 & 0.272 & 0.187 & 0.117 \\
\hline \multicolumn{4}{|c|}{ Sampling point: spring Solenica } \\
\hline 04.12 .2011 & -0.119 & -1.101 & -0.281 \\
\hline 08.01 .2012 & 0.549 & -0.131 & 0.387 \\
\hline 24.03 .2012 & 0.502 & -0.150 & 0.343 \\
\hline 15.04 .2012 & 0.659 & -0.421 & 0.502 \\
\hline 06.05 .2012 & 0.409 & -0.607 & 0.254 \\
\hline 22.06 .2012 & 0.010 & -0.899 & -0.144 \\
\hline 21.07.2012 & 0.321 & -0.572 & 0.171 \\
\hline 25.08 .2012 & 0.108 & -0.814 & -0.043 \\
\hline 02.10 .2012 & 0.679 & -0.074 & 0.527 \\
\hline 23.11 .2012 & -0.099 & -1.346 & -0.254 \\
\hline 15.12 .2012 & 0.312 & -0.892 & 0.148 \\
\hline 07.01 .2013 & 0.363 & -0.858 & 0.202 \\
\hline 10.02 .2013 & 0.413 & -0.532 & 0.254 \\
\hline 17.03.2013 & 0.978 & 0.132 & 0.820 \\
\hline 30.04 .2013 & 0.554 & -0.520 & 0.401 \\
\hline 06.05 .2013 & 0.465 & -0.288 & 0.312 \\
\hline 09.06 .2013 & 0.037 & -1.015 & -0.115 \\
\hline 28.07.2013 & 0.560 & -0.019 & 0.408 \\
\hline 01.08 .2013 & 0.349 & -0.567 & 0.197 \\
\hline 15.09.2013 & 0.673 & 0.003 & 0.521 \\
\hline 20.10 .2013 & 0.139 & -1.240 & -0.014 \\
\hline 08.11 .2013 & 0.790 & 0.436 & 0.635 \\
\hline
\end{tabular}




\section{CONCLUSION}

This study, as the first continuous hydrochemical research in the protected area Monument of nature "Slatinski Izvor", aimed at determination the hydrochemical properties and possible origin of the water of the springs Slatinski Izvor and Solenica. The first spring is located on carbonate rocks, and the second one is on a fault between carbonate and non-carbonate rocks. Between December 2011 and November 2013, a total of 21 water samples were collected from the Slatinski Izvor spring, and 22 from the Solenica spring. The measurements included temperature, $\mathrm{pH}$ and electrical conductivity, as well as mass concentrations of major ions of $\mathrm{Ca}, \mathrm{Mg}$, bicarbonate, chloride, sulfate, $\mathrm{K}, \mathrm{Na}$, nitrate, nitrite, ammonium and trace elements ( $\mathrm{Zn}, \mathrm{P}, \mathrm{Mn}, \mathrm{Fe}, \mathrm{Cu}, \mathrm{Cd}, \mathrm{Pb}, \mathrm{Co}$ ).

The results showed that the waters from the springs belong to the different sources. Also, the lithology of the springs is reflected in chemical composition of the waters.
The water of the Slatinski Izvor spring belongs to $\mathrm{Ca}-\mathrm{HCO}_{3}$ type. EC had low values which may be attributed to the short residence time of the water in the karst aquifer, and the spring had typical shallow and fresh water. The high value of the sulfate content pointed out that the origin of the water is from non-carbonate area, whereas the $\mathrm{Ca} / \mathrm{Mg}$ index showed the influence of mixed limestone-dolomite sequence in the carbonate area in which the water pass through.

The water of the Solenica spring belongs to $\mathrm{NaCl}$ water type. Because in the study area there is no evidence for the existence of evaporite rocks, on one hand, and high mineralization, high $\mathrm{Ca} / \mathrm{Mg}$ ratio, high $\mathrm{EC}$, and high $\mathrm{Cl}^{-}, \mathrm{Na}^{+}, \mathrm{SO}_{4}^{2-}, \mathrm{HCO}_{3}^{-}, \mathrm{Ca}^{2+}$, and $\mathrm{Mg}^{2+}$ content, on the other, the saline water from the spring would be probably deep ancient ground water, which had been retained in the pores of the sediments and had spent a relative long time in contact with the rocks of the aquifer.

\section{REFERENCES}

Allen, S.E. (ed.), 1989: Chemical analysis of ecological materials.- Blackwell scientific publication, pp. 368, Oxford-London-Edinburgh-Boston-Melbourne.

Bakalowicz, M., 2005: Karst groundwater: a challenge for new resources.- Hydrogeol. Journal, 13, 148-160. http://dx.doi.org/10.1007/s10040-004-0402-9

Chadha, D.K., 1999: A proposed new diagram for geochemical classification of natural waters and interpretation of chemical data.- Hydrogeology Journal, 7, 431-439. http://dx.doi.org/10.1007/ s100400050216

D’Amore, F., Scandiffio, G. \& C. Panichi, 1983: Some observations on the chemical classification of ground waters.- Geothermics, 12, 141-148. http://dx.doi. org/10.1016/0375-6505(83)90024-X

Dévai, I., Horváth, K. \& Gy. Dévai, 1973: Sulphate content determination of natural waters and descriptionn of a new photometric procedure.- Acta. Biol. Debrecina, 10-11, 129-142 (in Hungarian).

Dumurdzanov, N., Stojanov, R. \& K. Petrovski, 1979: Explanatory note of the General Geological Map of Kruševo 1:100 000 map sheet, Belgrade.

Dumurdzanov, N., Serafimovski, T. \& B.C. Burchfiel, 2005: Cenozoic tectonics of Macedonia and its relation to the South Balkan extensional regime.- Geological Society of America: Geosphere, 1, 1, 1-22. http://dx.doi.org/10.1130/ges00006.1
Fiske, C.H. \& Y. Subbarow, 1925: The colorimetric determination of phosphorus.- The Journal of Biological Chemistry, 66, 375-383.

Ford, D. \& P. Williams, 2007: Karst hydrogeology and geomorphology.- John Willey \& Sons Ltd, pp. 562, London. http://dx.doi.org/10.1002/9781118684986

Gičevski, B. \& S. Hristovski, 2013: Hydrochemical features of the Solenica water spring.- Geographical Reviews, 47, 37-43, Skopje (in Macedonian).

Hunkeler, D. \& J. Mudry, 2007: Hydrochemical methods.- In: Goldscheider, N. \& D. Drew (eds.) Methods in Karst Hydrogeology. Taylor \& Francis Group, pp. 93-121, London.

Jenko, K., 1956: Zusammenfassung. (Solquellen beid. Dörfern Slansko und Slansko und Slatina im Bezirk Kičevo).- Trudovi na geološki zavod 5, 245-250, Skopje (in Macedonian).

Kilchmann, S., Waber, H.N., Parriaux, A. \& M. Bensimon, 2004: Natural tracers in recent groundwaters from different Alpine aquifers.- Hydrogeology Journal, 12, 643-661. http://dx.doi.org/10.1007/ s10040-004-0366-9

Kotevski, Gj., 1987: Hydrogeology of the mineral, thermal and thermomoneral waters at the territory of SRM.- Samoupravna praktika, 357, Skopje (in Macedonian). 
Melloul, A.J. \& L.C. Goldenberg, 1998: Early-indicator signals of groundwater contamination: the case of seawater encroachment.- Environmental Geology, 33, 279-288. http://dx.doi.org/10.1007/ s002540050247

Official gazette of the Republic of Macedonia, 2006: Ordinance for special requirements of natural mineral waters safety, 32, 10-15.

Palmer, N.A., 2007: Cave geology.- Cave Books, pp. 454, Dayton, Ohio.

Piper, A.M., 1944: A graphical procedure in the geochemical interpretation of water analyses.- American Geophysical Union Transaction, 25, 914-923. http://dx.doi.org/10.1029/TR025i006p00914

Plummer, L.N., Jones, B.F. \& A.H. Truesdell, 1976: WATEQF - A Fortran IV version of WATEQ, A computer program for calculating chemical equilibria of natural waters.- U.S. Geological Survey Water Resources Investigations Report 76-13, pp.70, Reston.

Sawyer, G.N. \& D.L. McCarthy, 1967: Chemistry of sanitary engineers ( $2^{\text {nd }} e d$. .).- McGraw Hill, pp. 518, New York.

Stiff, H.A.Jr., 1951: The interpretation of chemical water analysis by means of patterns.- Journal of Petroleum Technology, 3, 10, 15-17. http://dx.doi. org/10.2118/951376-G
Škunca-Milovanović, S., Feliks, R. \& B. Đurović, 1990: Voda za piće - Standardne metode za ispitivanje higijenske ispravnosti.- Savezni zavod za zdravstvenu zaštitu, pp. 844, Beograd.

Temovski, M., 2012: Extension of karst rock outcrop in the Republic of Macedonia.- Geographical Reviews, 46, 21-35, Skopje (in Macedonian).

Trček, B. \& H. Zojer, 2010: Recharge of springs. In: Kresic, N. \& Z. Stevanovic (eds) Groundwater Hydrology of Springs. Engineering, Theory, Management, and Sustainability. Elsevier, pp. 87-127, Amsterdam-Boston-Heidelberg-London-New York-Oxford-Paris-San Diego-San Francisco-Singapore-Sydney-Tokyo. http://dx.doi.org/10.1016/ B978-1-85617-502-9.00003-7

White, W.B., 1999: Groundwater flow in karst aquifers.In: J.W. Delleur (ed.) The Handbook of Groundwater Engineering. CRC Press, chapter 18, 18/1-18/36, Boca Raton. 